\title{
Functional Change of Dextran-modified $\alpha$-amylase from Bacillus acidocaldarius
}

\author{
Samia A. Ahmed ${ }^{\#}$, El. M. El-Mahdy ${ }^{*}$, Amal M. Hashem and \\ H. A. Goda ${ }^{* *}$ \\ Department of Chemistry of Natural and Microbial Products, \\ NRC; * Department of Chemistry, Faculty of Science, Helwan \\ University, and ${ }^{* *}$ Research \& Development Center, Misr \\ University for Science and Technology, Cairo, Egypt.
}

\begin{abstract}
$\boldsymbol{\alpha}$-AMYLASE from Bacillus acidocaldarius was modified by covalent coupling to activated dextran with retained activity of $77.7 \%$. After conjugation, the enzyme was stable within a broader $\mathrm{pH}$ range than the native enzyme and its optimum temperature increased by $10^{\circ} \mathrm{C}$ compared to the native enzyme. The conjugated $\alpha$ amylase exhibited a higher $\mathrm{K}_{\mathrm{m}}$ (Michaelis constant), lower $\mathrm{V}_{\max }$ (maximal reaction rate) and lower $\mathrm{E}_{\mathrm{A}}$ (activation energy) than the native enzyme. Covalent attachment of $\alpha$ - amylase to activated dextran protected the enzyme against heat inactivation. In the presence of the substrate, the conjugated enzyme retained $68.2 \%$ of its original activity after incubation at $70^{\circ} \mathrm{C}$ for $30 \mathrm{~min}$ which was more than that retained by the native enzyme $(50.3 \%)$ under the same conditions. The calculated $t_{1 / 2}$ (half-life time) values of heat inactivation energy at $50,60{ }^{\circ} \mathrm{C}$ were 89 and $56 \mathrm{~min}$, respectively for the conjugated enzyme, whereas at these temperatures the native enzyme was less stable $\left(t_{1 / 2} 60\right.$ and $47 \mathrm{~min}$, respectively). The deactivation rate constant at $80{ }^{\circ} \mathrm{C}$ for the conjugated $\alpha$-amylase is about $11.9 \times 10^{-3} / \mathrm{min}$, which is lower than that of the native enzyme $\left(14.8 \times 10^{-3} / \mathrm{min}\right)$. Conjugated $\alpha$-amylase was more stable against chemical denaturation than the native enzyme, and retained $70.6 \%$ of its activity in presence of $\mathrm{CuSO}_{4}(10 \mathrm{mM})$ while the native form of retained only $34.1 \%$
\end{abstract}

Keywords: $\alpha$-amylase, B. acidocaldarius, Glycosylation, Thermal stability.

Amylases are among the most important hydrolytic enzymes for all starch based industries, and the commercialization of amylases is oldest with first use in 1984, as a pharmaceutical aid for the treatment of digestive disorders (Gupta et al., 2003). In present day, amylases find application in all industrial processes such as in food, detergents, textiles, paper industries, fermentation, pharmaceutical industries and have completely replaced chemical hydrolysis in the starch

\footnotetext{
\# Author for correspondence: Samia A. Ahmed

Telephone: 002026347972

Fax: $\quad 002023370931$

E-mail: dr_Sa_Ahmed@yahoo.com
} 
processing industry (Alva et al., 2007 ; Ahmed et al., 2008 and De Souza \& Magalhaes, 2010). $\alpha$-amylase (endo-1,4- $\alpha$-D- glucan glucanohydrolase EC 3.2.1.1) are extra-cellular endo-enzymes that randomly cleave the 1,4- $\alpha$ linkages between adjacent glucose unit in the linear amylose chain and ultimately generates glucose, maltose and maltotriose units (Gupta et al., 2003). The stability of enzymes in vitro remains a critical issue in biotechnology. Both storage and operational stabilities affect the usefulness of enzyme-based products (Fagain, 2003). Therefore, there is a continuing demand to improve the stability of enzymes and to meet the requirements set by specific applications (Prakash \& Jaiswal, 2010 and David et al., 2011). It was demonstrated in a number of studies that the stability of some enzymes is enhanced using covalent attachment to water-soluble polymers (Ben Ammar et al., 2002 and Ahmed et al., 2007). However, critical analysis leads to the conclusion that frequently the observed stabilization was due to chemical modification or reduction of autolysis (Klibanov, 1979). Historically, carbohydrate compounds have been extensively used as modifying agents for enzymes (Gomez et al., 2000). It is postulated that one of the functions of these carbohydrate residues is to stabilize the threedimensional structure of the protein moiety of the glucoenzyme (Klibanov, 1979). Immobilized enzymes bound to a polymeric matrix are often prepared for the purpose of changing some of their properties, in particular to obtain complexes which exhibit an increased stability towards thermal denaturation, proteolytic degradation and other unfavorable conditions. An increase in thermal resistance and changes in the $\mathrm{pH}$ activity profile have been observed for enzymes immobilized on soluble supports such as polysaccharides (dextran, CM-cellulose and DEAE-dextran) (Lenders \& Crichton, 1984 and Fernandez et al., 2004). This is connected with their availability, easy modification, and hydrophily (Manaev et al., 1985). In this study, we have addressed the possibilities of using activated polysaccharides to improve $\alpha$-amylase stabilization via covalent attachment, focusing our attention on the enzymatic properties of the native and conjugated enzyme.

\footnotetext{
Materials and Methods

Microorganism

Bacillus acidocaldarius was isolated by Dr. Mona Esawy, Department of Chemistry of Natural and Microbial Products, NRC, Egypt. It was identified according to Bergey's Manual in Micro Analytical Center, Cairo University, Egypt. The culture was maintained on nutrient agar medium at $30^{\circ} \mathrm{C}$ for $48 \mathrm{hr}$ and stored at $4^{\circ} \mathrm{C}$.

\section{Growth medium and cultivation}

Basal medium for liquid culture consists of $(\mathrm{g} / \mathrm{l})$ : Starch, 10; nutrient broth, 2.5; $\mathrm{CaCl}_{2}, 0.5$ and the $\mathrm{pH}$ was adjusted to 7.0 before autoclaving. The same medium was also used for inoculum preparation. Cultivation was in 250-ml Erlenmeyer flasks containing $50 \mathrm{ml}$ of sterile medium. The flasks were inoculated with $1 \mathrm{ml}$ of a $24 \mathrm{hr}$-old culture and incubated at $40^{\circ} \mathrm{C}$ for $42 \mathrm{hr}$ with shaking at $200 \mathrm{rpm}$. The cultures were then centrifuged at $10000 \mathrm{x} \mathrm{g}$ for $15 \mathrm{~min}$ in a refrigerated centrifuge at $4{ }^{\circ} \mathrm{C}$.
}

Egypt. J. Microbiol. 46 (2011) 
Fractional precipitation with acetone

The crude enzyme prepared as described above was added slowly to two fold cold acetone $(\mathrm{v} / \mathrm{v})$ under constant stirring. The mixture was allowed to stand for $1 \mathrm{hr}$ at $4^{\circ} \mathrm{C}$ and the enzyme fraction was dried over anhydrous calcium chloride under decreased pressure at room temperature. The fraction was tested for enzyme activity and was used for enzyme chemical modification.

\section{Assay for $\alpha$-amylase activity}

$\alpha$ - amylase activity was determined according to Apar \& Ozbek (2005) $200 \mu \mathrm{l}$ of the enzyme were incubated with $1 \mathrm{ml}$ of $0.2 \%$ soluble starch in acetate buffer (0.05 M; pH 5.9) at $40{ }^{\circ} \mathrm{C}$ for $10 \mathrm{~min} .200 \mu \mathrm{l}$ of the reaction mixture was added to $5 \mathrm{ml}$ of an iodine solution to stop the reaction. The degradation of starch by the enzyme was measured at $620 \mathrm{~nm}$. One unit of $\alpha$-amylase activity was defined as the quantity of enzyme required to hydrolysis of $0.1 \mathrm{mg}$ starch under assay conditions. All the results reported are the mean of at least three separate experiments.

\section{Protein estimation}

Protein was determined according to the method of Lowry et al. (1951) using bovine serum albumin as standard

Carbohydrates used for the enzyme chemical modification

Pectin (MW 30x10 $-100 \times 10^{3}$ ), dextran (MW $70 \times 10^{3}$ ) and dextran $\left(\mathrm{MW} 80 \times 10^{3}\right.$ ) were from Sigma Chemical Co., USA.

\section{Preparation of sodium periodate activated polysaccharides}

$\alpha$ - amylase was coupled to soluble polysaccharides by the method reported by Ben Ammar et al. (2002) as follows: $250 \mathrm{mg}$ of each polysaccharide were dissolved in $10 \mathrm{ml}$ of $0.25 \mathrm{M}$ sodium periodate solution and allowed to stand at $30^{\circ} \mathrm{C}$ for $6 \mathrm{hr}$, then $0.3 \mathrm{ml}$ of ethylene glycol were added and allowed to react for $1 \mathrm{hr}$. The reaction mixture was dialyzed against water at $4^{\circ} \mathrm{C}$ overnight, and then lyophilized.

Enzyme coupling with activated polysaccharides

Partially purified $\alpha$ - amylase $(0.4 \mathrm{mg})$ and oxidized polysaccharides $(100 \mathrm{mg})$ were combined in acetate buffer $(0.05 \mathrm{M}$; pH 5.9). The reaction mixture was allowed to stand at $4{ }^{\circ} \mathrm{C}$ overnight. The conjugates were precipitated at $50 \%$ ethanol and lyophilized.

\section{Temperature profiles}

Enzyme activities of both native and conjugated form were determined at indicated temperatures $\left(30-80^{\circ} \mathrm{C}\right)$. The temperature data were replotted in the form of Arrhenius plots and the slope is related to the activation energy $\left(\mathrm{E}_{\mathrm{A}}\right)$ for the molecule by the relationship:

$$
\text { Slope }=E_{A} / 2.303 R
$$

where $\mathrm{R}$ is the gas constant $(\mathrm{R}=1.976 \mathrm{Cal} / \mathrm{mol})$. 


\section{Thermal stability}

The thermal stability was determined by measuring the residual activity of the enzyme exposed at a temperature range from 50 to $80^{\circ} \mathrm{C}$ for different periods (15-90 min). Plotting activity data, Log of residual activity as a function of the time and the slope is related to the deactivation rate constant. Determination of the half life another important parameter related to enzyme stability. The enzyme half life $\left(t_{1 / 2}\right)$ corresponds to the time period necessary for the residual enzyme activity to decrease to $50 \%$ of its initial value and it was calculated from the following equation:

$$
\mathrm{t}_{1 / 2}=0.3 / \text { Deactivation rate constant }
$$

\section{Effect of reaction $\mathrm{pH}$ and $\mathrm{pH}$ stability}

The effect of $\mathrm{pH}$ value on the activity of free and conjugated was investigated using buffer $(0.05 \mathrm{M})$ with different $\mathrm{pHs}$ (from 5.0 to 8.0 ). The $\mathrm{pH}$ stability of $\alpha$ amylase was determined after pre-incubating the enzyme for $1 \mathrm{hr}$ at $30^{\circ} \mathrm{C}$ with buffer $(0.05 \mathrm{M})$ at different $\mathrm{pHs}$ (from 5.0 to 9.5 ), followed by adjusting the $\mathrm{pH}$ to the value of standard assay system.

\section{Results and Discussion}

The stabilization of enzymes is very important, especially when the stability is required for the industrial use of the enzyme of interest. In this study, a method to stabilize $\alpha$ - amylase from $B$. acidocaldarius was achieved using simple and quick method. It depends on the oxidation state of different polysaccharides with periodate to produce a dialdehyde with two free hydroxyl groups able to link with the $\alpha$ amylase molecule with any cross-linkage agent. It was reported that protein glycosylation might affect the hydrophilic/ hydrophobic balance and/ or net charge at the protein surface, leading to changes in protein-solvent and protein-protein interactions. These, in turn, could lead to changes in folding, stability, protease resistance, or biologic activity of glycosylated proteins (Pedrosa et al., 2000). Among all preparations (Table 1), the enzyme conjugated to dextran (MW $70 \times 10^{3}$ ) showed the highest retained activity $(77.7 \%)$ of the specific activity of the native enzyme and was selected for further investigations. The $23 \%$ decrease in specific activity after glycosylation could be attributed to the rigidification of the enzyme protein conformation (Lenders \& Crichton, 1984 and Fernandez et al., 2004). On the other hand, Gottschalk \& Jaenicke (1991) deduced that the covalent attachment of the enzyme to the immobilization matrix would also lead to a decrease in catalytic activity owing to the decrease in the flexibility of the enzyme molecule. The drop of the specific activity after the glycosylation of other enzymes were previously reported (Abdel-Naby, 1999 and Ben Ammar et al., 2002).

Properties of the native and conjugated $\alpha$-amylase enzyme

The optimum $\mathrm{pH}$ of the native and dextran conjugated $\alpha$ - amylase was studied using different $\mathrm{pHs}$ values ranging from 5.0 to 8.0. The results (Fig. 1) indicated that the two forms of $\alpha$ - amylase expressed an activity optimum at $\mathrm{pH} 7.25$. This means that the ionization of the amino acid residues at the active site remains unaffected by the glycosylation process. Similar result was reported for other glycosylated amylase (Srivastava, 1991).

Egypt. J. Microbiol. 46 (2011) 
FUNCTIONAL CHANGE OF DEXTRAN-MODIFIED ...

TABLE 1. Covalent coupling of $B$. acidocaldarius $\alpha$-amylase to activated polysaccharides.

\begin{tabular}{|l|c|c|c|c|}
\hline \multirow{2}{*}{$\begin{array}{c}\text { Activated } \\
\text { polysaccharides }\end{array}$} & \multicolumn{2}{|c|}{ Coupled enzyme } & $\begin{array}{c}\text { Specific activity of } \\
\text { conjugates } \\
\text { (U/ mg protein) }\end{array}$ & $\begin{array}{c}\text { Recovered } \\
\text { activity } \\
\text { (\%) }\end{array}$ \\
\cline { 2 - 3 } & $\begin{array}{c}\text { Protein } \\
(\mathbf{m g})\end{array}$ & $\begin{array}{c}\text { Activity } \\
\text { (U) }\end{array}$ & & \\
\hline $\begin{array}{l}\text { Pectin } \\
30 \times 10^{3}-100 \times 10^{3}\end{array}$ & 2.7 & 1382.4 & 512 & 31.4 \\
\hline $\begin{array}{l}\text { Dextran } \\
70 \times 10^{3}\end{array}$ & 1.9 & 2408.5 & 3965.39 & 77.74 \\
\hline $\begin{array}{l}\text { Dextran } \\
80 \times 10^{3}\end{array}$ & 1.45 & 1608.5 & 1109.3 & 68.03 \\
\hline
\end{tabular}

Enzyme added to one gram activated polysaccharides in $1.40 \mathrm{mg}$ protein containing $7141.17 \mathrm{U}$

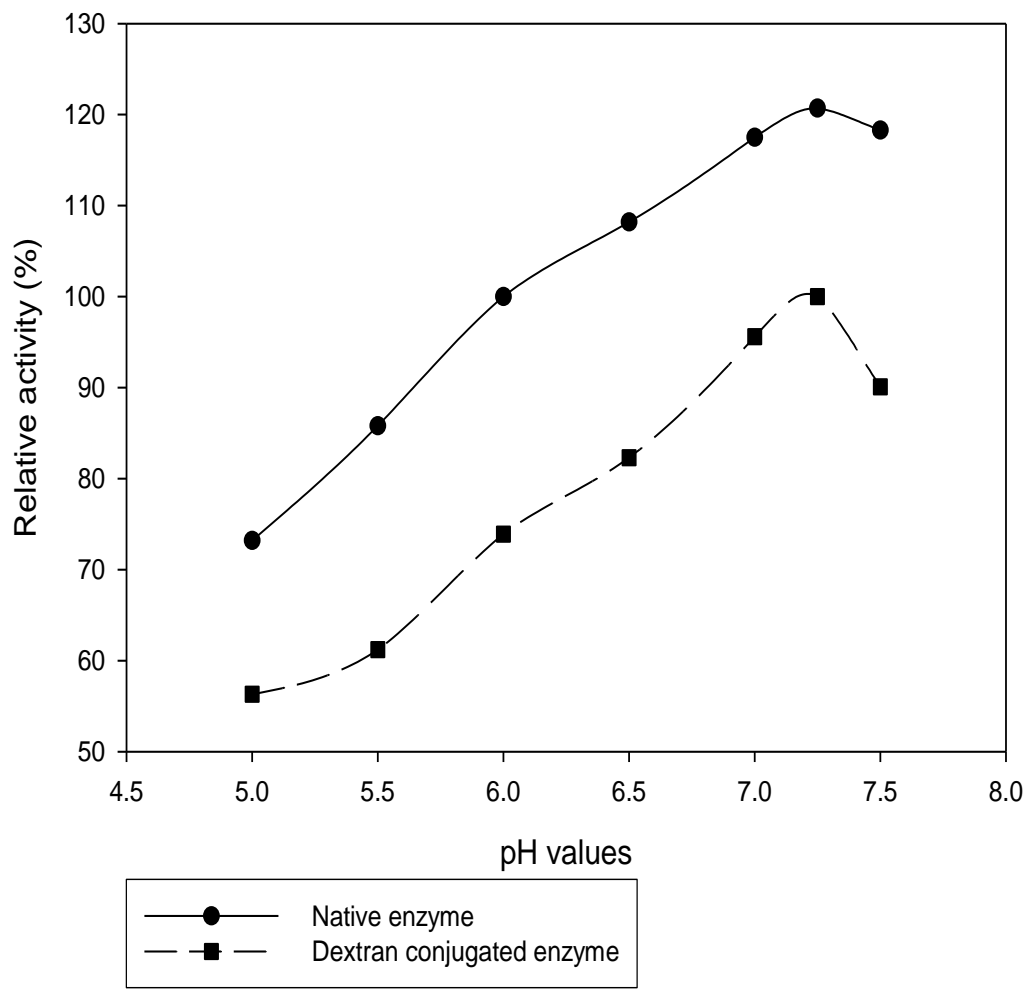

Fig.1. Effect of pH of the reaction on the activity of native and dextran conjugated $\alpha$-amylase.

Egypt. J. Microbiol. 46 (2011) 
Activities of native and conjugated $\alpha$ - amylase were assayed at various temperatures $\left(30-70^{\circ} \mathrm{C}\right)$. The temperature optimum of the enzyme shifted from $50^{\circ} \mathrm{C}$ to $60^{\circ} \mathrm{C}$ upon conjugation (Fig. 2). The increase of the temperature is probably a consequence of enhanced thermal stability. El-Refai (2000) reported the changes in the optimal temperature of bacterial cyclodextrin glucosyltransferase from 65 to $80^{\circ} \mathrm{C}$ after glycosylation. Fernandez et al. (2004) reported changes in the optimal temperature of $\alpha$-chymotrypsin after glycosylation. The plots for both the native and conjugated enzyme were linear (Fig. 3) and the values of the energy of activation were calculated as 2.37 and $2.23 \mathrm{Kcal} / \mathrm{mol}$, respectively. This result indicated that the applied glycosylation procedure introduced changes in the structure of the enzyme molecule which enhanced its catalytic properties. A similar result was reported for other enzymes by Ahmed et al. (2007). Abdel-Naby (1999) pointed to the decreased in activation energy of Aspergillus niger cellobiase enzyme after glycosylation.

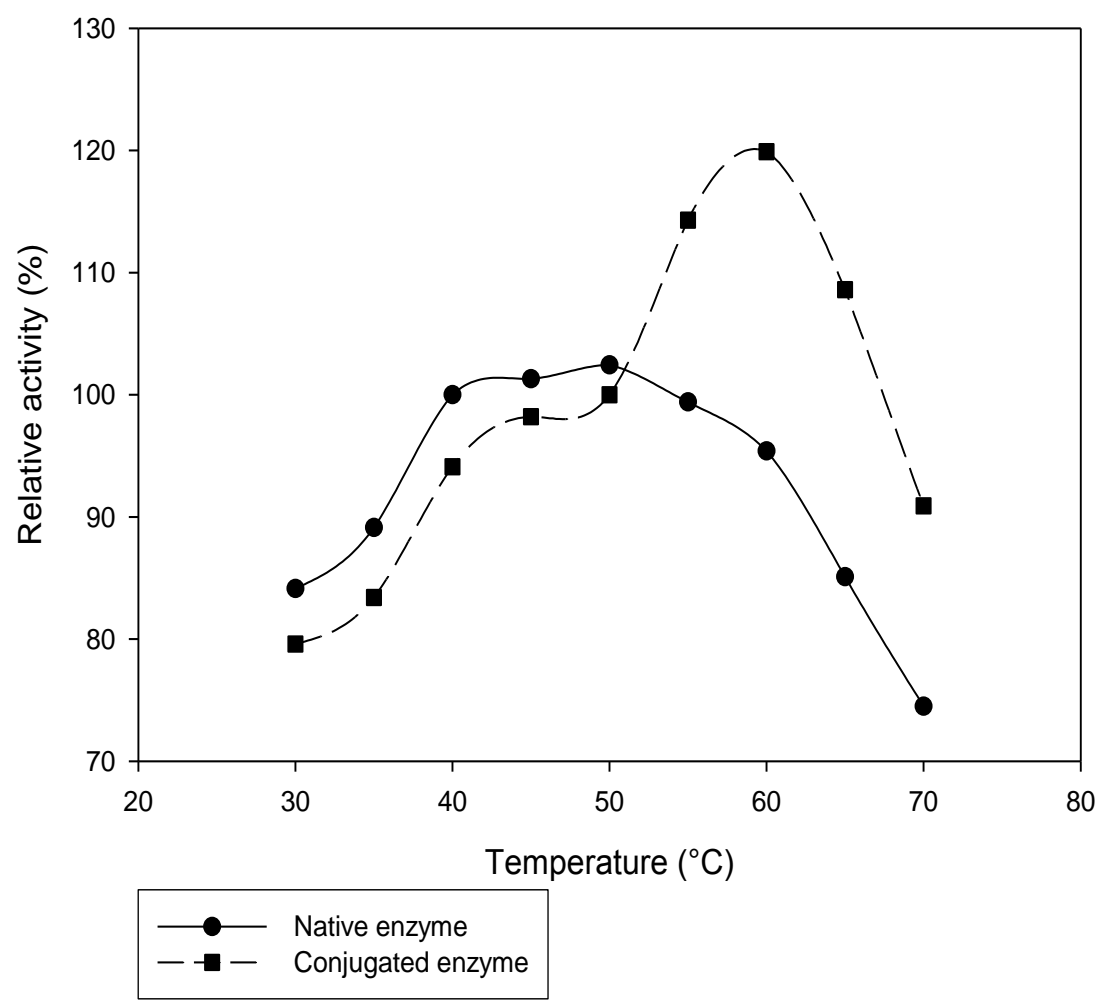

Fig.2. Effect of temperature of the reaction on the activity of native and dextran conjugated $\alpha$-amylase.

Egypt. J. Microbiol. 46 (2011) 


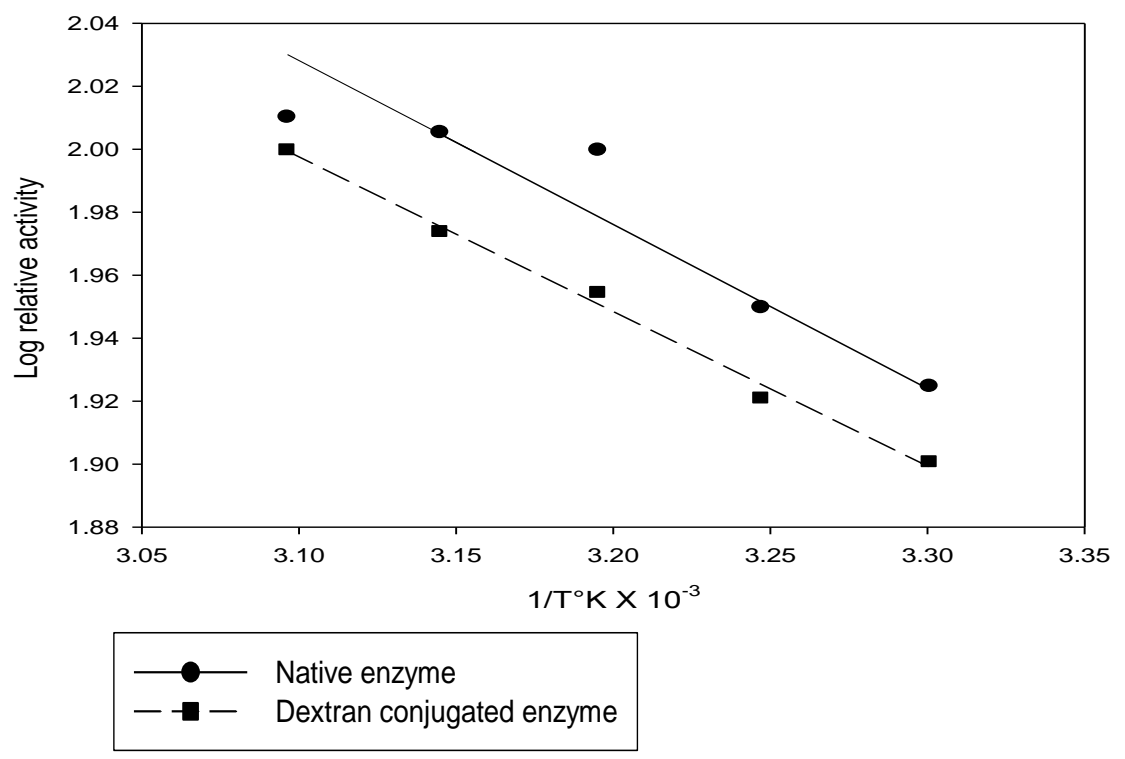

Fig.3. Arrhenius plots for the native and dextran conjugated $\alpha$-amylase .

Lineweaver-Burk plots of the native and conjugated $\alpha$ - amylase with potato starch (Fig. 4) gave $\mathrm{K}_{\mathrm{m}}$ (Michaelis constant) of 0.86 and $0.92 \mathrm{mg} / \mathrm{ml}$, respectively. The $\mathrm{V}_{\max }$ (maximal reaction rate) of the native and conjugated $\alpha$-amylase were 144.1 and $122.7 \mathrm{U} / \mathrm{mg}$ protein, respectively. The apparent increase of $\mathrm{K}_{\mathrm{m}}$ value after conjugation is most likely a consequence of conformational changes in the enzyme introduced by the glycosylation procedure which renders its active site less accessible to the substrate. Consequently, the maximum reaction rate of the enzyme-catalyzed reaction was lower than the native enzyme (Gottschalk \& Jaenicke, 1991). The increase of $\mathrm{K}_{\mathrm{m}}$ value and decrease of the $\mathrm{V}_{\max }$ after stabilization of cellobiase by covalent coupling to soluble polysaccharide was reported by Abdel-Naby (1999).

The rates of heat inactivation of the native and conjugated $\alpha$-amylase were investigated (Table 2). In general, covalent attachment of dextran to $\alpha$-amylase molecule protected the enzyme against heat inactivation. For example, the calculated half-life values $\left(\mathrm{t}_{1 / 2}\right)$ showed that the heat inactivation of the conjugated enzyme at 50 and $60^{\circ} \mathrm{C}$ were 89 and $56 \mathrm{~min}$, respectively whereas the native enzyme was less stable ( $\mathrm{t}_{1 / 2}$ of 60 and $47 \mathrm{~min}$, respectively). The deactivation rate constant at $80^{\circ} \mathrm{C}$ for the conjugated $\alpha$-amylase is about $11.9 \times 10^{-3} \mathrm{~min}$ which is lower than that of the native $\alpha$ - amylase $\left(14.8 \times 10^{-3} \mathrm{~min}\right)$. The mechanism involved in the carbohydrate-induced stability of glycosylated proteins by rigidification of the conformation has already been discussed (Klibanov, 1983). On the other hand, Srivastava (1991) argued that the hydration effect of the 
attached carbohydrate may be responsible for improving the stability of conjugated enzymes. Fernandez et al. (2004) reported that the modified $\alpha$ chymotrypsin was more resistant to thermal inactivation at different temperatures.

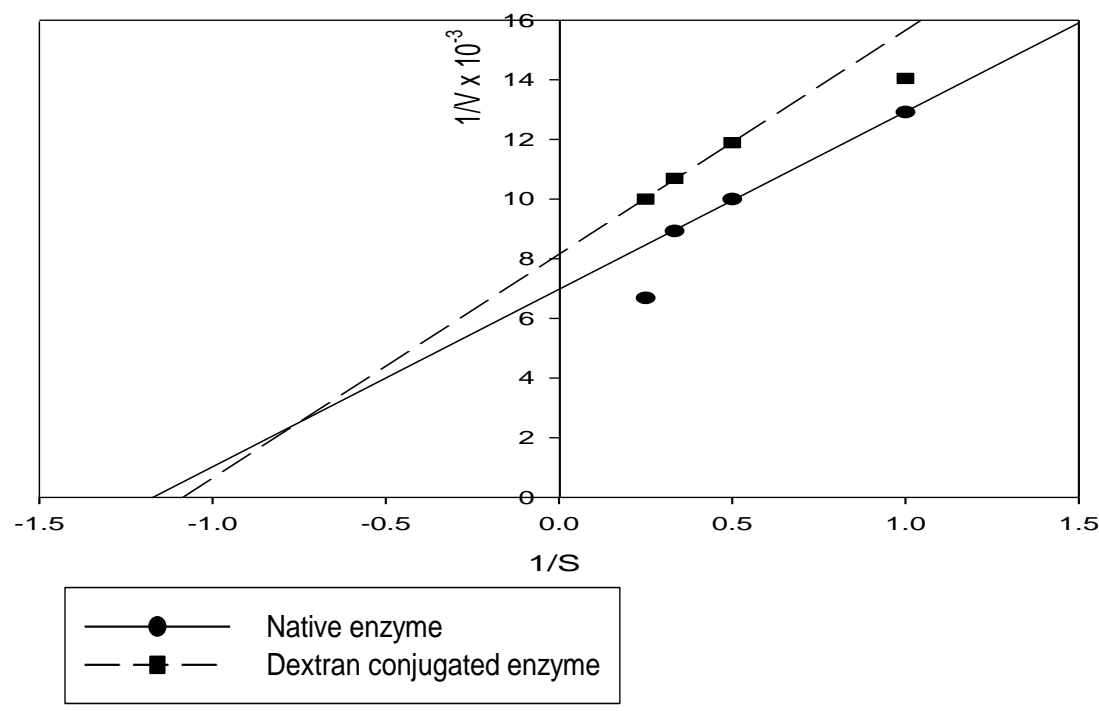

Fig.4. Lineweaver-Bulk plot of native and dextran conjugated $\alpha$-amylase.

TABLE 2. Thermal stability of native and dextran conjugated $\alpha$-amylase.

\begin{tabular}{|c|c|c|c|c|c|c|c|c|}
\hline \multirow{3}{*}{$\begin{array}{l}\text { Time of } \\
\text { heating } \\
(\text { min) }\end{array}$} & \multicolumn{8}{|c|}{ Residual activity (\%) } \\
\hline & \multicolumn{4}{|c|}{ Native enzyme } & \multicolumn{4}{|c|}{ Conjugated enzyme } \\
\hline & 50 & 60 & 70 & 80 & 50 & 60 & 70 & 80 \\
\hline Zero & 100 & 100 & 100 & 100 & 100 & 100 & 100 & 100 \\
\hline 15 & 85.0 & 80.5 & 67.2 & 57.5 & 89.9 & 84.7 & 79.6 & 66.6 \\
\hline 30 & 71.1 & 65.1 & 50.3 & 30.6 & 78.5 & 71.6 & 68.2 & 57.6 \\
\hline 45 & 65.0 & 50.5 & 34.9 & 2.1 & 70.2 & 66.5 & 54.7 & 33.7 \\
\hline 60 & 58.5 & 37.5 & 33.5 & 0 & 63.1 & 54.6 & 48.6 & 20.4 \\
\hline 75 & 25.4 & 13.6 & 4.3 & 0 & 48.3 & 37.8 & 21.6 & 11.9 \\
\hline 90 & 4.5 & 0 & 0 & 0 & 23.6 & 17.9 & 11.6 & 7.0 \\
\hline
\end{tabular}


The results shown in Fig. 5 demonstrate that $\alpha$ - amylase conjugated with dextran was significantly more stable against incubation at different $\mathrm{pH}$ values (6.0-9.5) than the native enzyme. Fernandez et al. (2004) found that, $\alpha$ chymotrypsin stabilized by chemical modification was more stable at $\mathrm{pH} 9.0$ than the native enzyme.

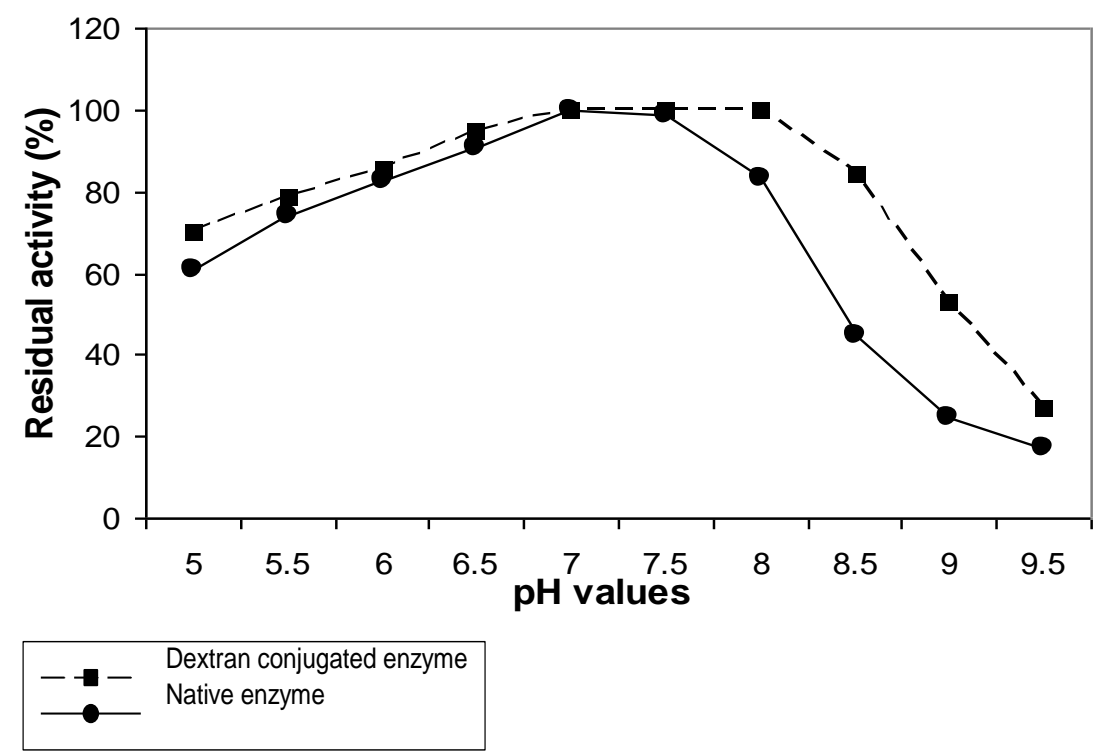

Fig. 5. pH stability of native and dextran conjugated $\alpha$-amylase .

The enzyme activity was assayed after incubating with various metal ions $(10 \mathrm{mM})$ at $30^{\circ} \mathrm{C}$ for $30 \mathrm{~min}$ (Fig. 6). In general, it was observed that the inhibitory effect of the investigated metal ions was less pronounced with the conjugated enzyme as compared with the free $\alpha$-amylase. The results pointed to the inhibitory effect of most metal ions tested on the activity of native and conjugated enzyme. Treatment of proteins with high water-binding salts (like $\mathrm{MgSO}_{4}$ ) reduces the water shield surrounding them and consequently, the stability was negatively affected. In case of the conjugated $\alpha$-amylase water shield was probably preserved due to the hydrophilic nature of the polysaccharide attached to it, the water shield was probably preserved. A similar explanation was given by Srivastava (1991). On the other hand, $\mathrm{Cu}^{2+}$ ion decreased the enzyme activity, this inhibitory effect was higher in the native enzyme $(65.9 \%)$ than the modified enzyme $(29.4 \%)$. The results revealed that the glycosylation of $\alpha$-amylase formed stable covalent bonds that led to achievement of resistance against chemical and thermal denaturation. 


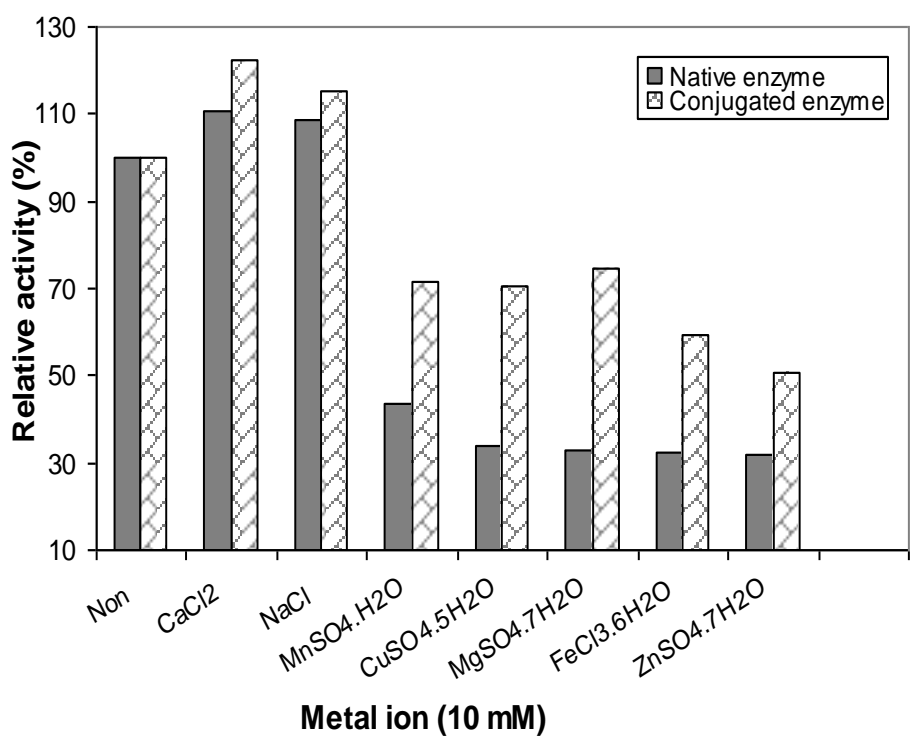

Fig.6. Effect of some metal ions on the activity of native and dextran conjugated $\alpha$ amylase.

\section{References}

Abdel-Naby, M.A. (1999) Stabilization of cellobiase by covalent coupling to soluble polysaccharide. Microbiol . Research, 154(2), 213-21.

Ahmed, S.A., El- Mahdy, E.M., Hassan, O-K.K., Saleh, N.A. and Goda, H.A. (2008) Studies on the activity and stability of immobilized Bacillus acidocaldarius alphaamylase. Aust. J. of Basic and Appl. Sci. 2(3), 466-474.

Ahmed, S.A., Saleh, S.A. and Abdel-Fattah, A.F. (2007) Stabilization of Bacillus licheniformis ATCC 21415 alkaline protease by immobilization and modification. Aus. J. Basic and Appl. Sci. 1(3), 313-322.

Alva, S., Anupama, J., Savla, J., Chiu, Y.Y., Vyshali, P., Shruti, M., Yogeetha, B.S., Bhavya, D., Puri, J., Ruchi, K., Kumudini, B. and Varalakhmi, K.N. (2007) Production and characterization of fungal amylase enzyme isolated from Aspergillus sp. JGl 12 in solid state culture. Afri. J. Biotech. 6(5), 576-581.

Apar, D. K. and Ozbek, B. (2005) $\alpha$-amylase inactivation during starch hydrolysis. Proc. Biochem. 40, 1367-1379.

Ben Ammar, Y., Matsubara, T., Ito, K., Iizuka, M. and Minamiura, N. (2002) Some properties of levansucrase of Bacillus natto stabilized with periodate oxidized yeast glucomannan. Enzy. and Microb. Technol. 30, 875-882.

Egypt. J. Microbiol. 46 (2011) 
David, A.E., Yang, A.J. and Wang, N.S. (2011) Enzyme stabilization and immobilization by sol-gel entrapment. Methods Mol. Biol. 679, 49-66.

De Souza, P.M. and Magalhaes, P.deO. (2010) Application of microbial $\alpha$-amylase in industry- A review. Baraz. J. Microbiol. 41, 850-861.

Fagain, C.O. (2003) Enzyme stabilization recent experimental progress. Enzy. Microb. Technol. 33, 137-149.

El-Refai, H.A.H. (2000) Studies on cyclodextrin glucosyltransferases from bacteria. Ph.D Thesis- Helwan, Egypt: National Research Centre, Cairo, Egypt.

Fernandez, M., Villalonga, M. L., Fragoso, A., Cao, R., Banos, M. and Villalonga, R. (2004) $\alpha$-Chymotrypsin stabilization by chemical conjugation with $O$ - carboxymethyl-polyß-cyclodextrin. Proc. Biochem. 39, 535-539.

Gomez, L., Ramirez, H.L. and Villalong, R. (2000) Stabilization of invertase by modification of sugar chain with chitosan. Biotech. letter, 23, 347-350.

Gottschalk, N. and Jaenicke, R. (1991) Authenticity and reconstitution of immobilized enzymes: Characterization, denaturation and renaturation of glucoamylase. Appl. Biotech. Biochem. 14, 324-335.

Guptua, R., Gigras, P., Mohapatra, H., Goswami, V.K. and Chauhan, B. (2003) Microbial $\alpha$-amylase: a biotechnological perspective. Proc. Biochem. 38, 1599-1616.

Klibanov, A.M. (1979) Enzyme stabilization by immobilization. Analyt.Biochem. 39, 1-25.

Klibanov, A.M. (1983) Immobilized enzymes and cells as practical catalysts. Sci. 219, 722727.

Lenders, J.P. and Crichton, R.R. (1984) Thermal stabilization of amylolytic enzymes by covalent coupling to soluble polysaccharides. Biotechnol. and Bioeng. 26, 1343-1351

Lowry, O.H., Rosebrough, N.J., Farr, A.L. and Ranall, R.T. (1951) Protein measurement with the folin phenol reagent. J. Biologi. Chem., 193, 265-273.

Manaev, B.M., Yamskov, I.A., Ashubaeva, Z.D. and Davankov, V.A. (1985) Prikladnaya Biokhim. i Microbiol. 21(1), 58-62.

Pedrosa, C., De Felice, F.G., Trisciuzzi, C. and Ferriera, S. T. (2000) Selective new glycosylation increases the structural stability of vicilin the $7 \mathrm{~S}$ storage globulin from pea seeds. Archi. Biochem. Biophy. 382, 203-210.

Prakash, O. and Jaiswal, N. (2010) Alpha- amylase: an ideal representative of thermostable enzymes. Appl. Biotechnol. 160(8), 2401-2414.

Srivastava, R.A.K. (1991) Studies on stabilization of amylase by covalent coupling to soluble polysaccharides. Enzy.and Microb. Technol. 13, 164-170. 


\title{
التغير الوظيفى لانزيم ألفا أميليز المعدل بالدكستران والمنتج بواسطة \\ Bacillus acidocaldarius
}

\author{
سامية عبد العزيز أحمد ، السيد محمد المهاى"، أمال محمد عبد الجواد هاشم و

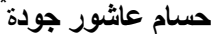

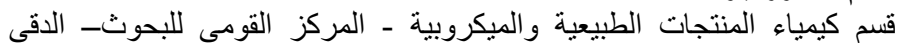

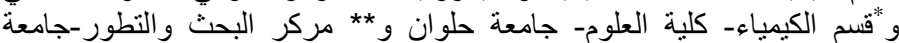 \\ مصر للعلوم و التكنولوجيا- القاهرة - مصر.
}

تهدف هذه الدراسة إلى محاوله تعديل انزيم ألفا أميليز المنتج بواسطة سلالة وBacillus acidocaldarius وقد تم ذلك عن طريق الأرتباط التساهمى للأنزيم مع بعض النير السكريات العديدة

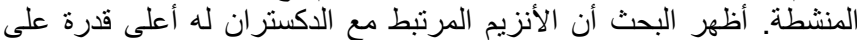

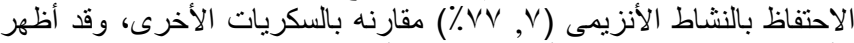

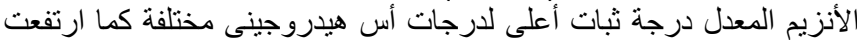

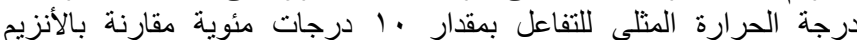

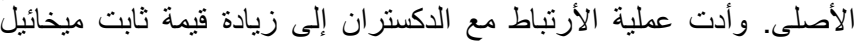
و انخفاض قيمة معدل السرعة القصوى للتفاعل (K)

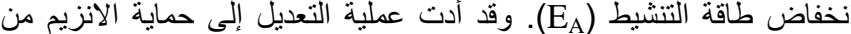

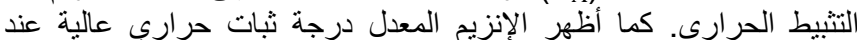

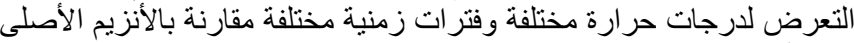

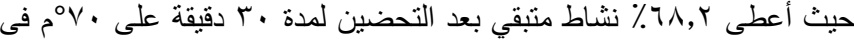

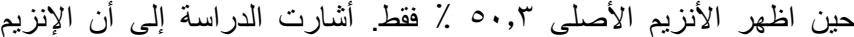

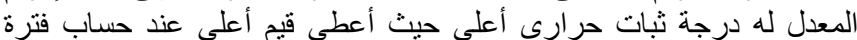

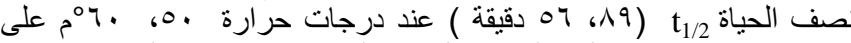

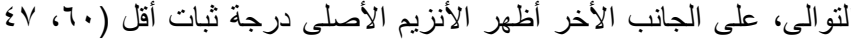

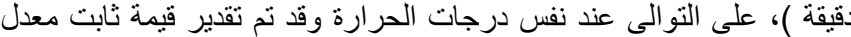

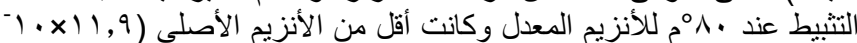

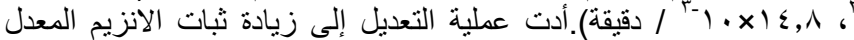

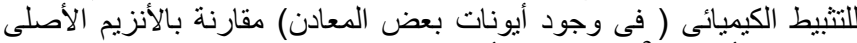

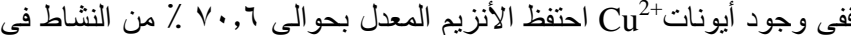

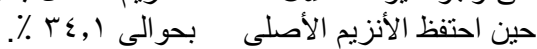

